\title{
Isolation and purification of total RNA from Streptococcus mutans in suspension cultures and biofilms
}

\author{
Jaime Aparecido Cury(a) \\ Jennifer Seils(b) \\ Hyun Koo ${ }^{(c)}$ \\ (a) Professor of Biochemistry and Cariology, \\ Piracicaba Dental School, State University of \\ Campinas, Piracicaba, SP, Brazil. \\ (b) Laboratory Technician Associate; (c) Assistant \\ Professor of Dentistry, Microbiology and \\ Immunology - Eastman Department \\ of Dentistry, Center for Oral Biology \\ and Department of Microbiology and \\ Immunology, University of Rochester \\ Medical Center, Rochester, NY, USA.
}

\begin{abstract}
The presence of extracellular polysaccharides matrix makes extraction and purification of RNA from Streptococcus mutans within biofilms challenging. In this study, several approaches to purify RNA extracted from $S$. mutans in suspension cultures and biofilms were examined. The combination of sonication ( 3 pulses of $30 \mathrm{~s}$ at $7 \mathrm{~W}$ ), suspension in NAES buffer $(50 \mathrm{mM}$ sodium acetate buffer, $10 \mathrm{mM}$ EDTA and $1 \%$ SDS; pH 5.0) and homogenization-mechanical cells disruption in NAESacid phenol:chloroform, yielded $9.04 \mathrm{mg}$ (or $0.52 \mathrm{mg}$ ) of crude preparation of RNA per $100 \mathrm{mg}$ of total cell (or biofilm) dry-weight. The crude RNA preparations were subjected to various DNAse I treatments. The combination of DNAse I in silica-gel based column followed by recombinant DNase I in solution provided the best genomic DNA removal, resulting in $4.35 \mathrm{mg}$ (or $0.06 \mathrm{mg}$ ) of purified RNA per $100 \mathrm{mg}$ of total cell (or biofilm) dry-weight. The cDNAs generated from the purified RNA sample were efficiently amplified using gtfB $S$. mutans-specific primers. The results showed a method that yields high-quality RNA from both planktonic cells and biofilms of $S$. mutans in sufficient quantity and quality for real-time RT-PCR analyses.
\end{abstract}

Descriptors: Dental plaque; Streptococcus mutans; Polymerase chain reaction; RNA; Polysaccharides.

\author{
Corresponding author: \\ Hyun Koo \\ University of Rochester Medical Center \\ Eastman Department of Dentistry and Center \\ for Oral Biology \\ 625 Elmwood Ave., Box 683 \\ Rochester, NY 14620 (USA) \\ E-mail: Hyun_Koo@urmc.rochester.edu
}

Received for publication on Mar 29, 2007

Accepted for publication on Dec 15, 2007 


\section{Introduction}

Real-time reverse transcription-polymerase chain reaction (RT-PCR) is the most sensitive and precise method to measure low abundance gene expression in biological samples. ${ }^{1}$ Determination of mRNA levels using real-time RT-PCR by monitoring formation of PCR products (amplicons) with the fluorescence dye SYBR Green I is being extensively used in biomedical sciences, including oral microbiology; SYBR Green I fluorescence dye binds specifically to the minor groove double-stranded DNA. ${ }^{2}$

Real-time RT-PCR in general is a reliable technique, but requires a reproducible and well-defined methodology for RNA extraction and purification for accurate determination of mRNA levels. Several methods of RNA extraction and purification have been reported for oral bacteria grown in planktonic state, including oral streptococci. ${ }^{3-8}$ In contrast to planktonic cells, RNA isolation from microorganisms within biofilms is challenging because of the presence of an extracellular polysaccharide matrix, which may interfere with the extraction and purification of the nucleic acids, especially with genomic DNA removal. ${ }^{9}$ RNA isolation and purification from polysaccharide-rich tissues, such as in plants and fruits, are difficult because these polymeric substances bind to nucleic acids, inhibit translational activity of RNA and interfere with DNAse activity. ${ }^{10-12}$ Therefore, a RNA isolation and purification method that consistently yields high quality RNA from both planktonic cells and biofilms in sufficient quantity for functional genomic based experiments such as real-time PCR would be useful.

In this study, several methods of RNA purification were examined using Streptococcus mutans in suspension cultures and biofilms as source of RNA.

\section{Materials and Methods Preparation of planktonic cells and biofilms of S. mutans UA159}

Planktonic cells of Streptococcus mutans UA159 (serotype c) $)^{13}$ were grown in $10 \mathrm{ml}$ of ultrafiltered (Prep/Scale, Millipore Co., Billerica, MA, USA) tryptone-yeast extract broth $(2.5 \%$ tryptone and $1.5 \%$ yeast extract, $\mathrm{pH} 7.0$ ) with $1 \%$ glucose. ${ }^{14}$ Biofilms of $S$. mutans UA159 were formed on standard glass microscope slides (surface area of $37.5 \mathrm{~cm}^{2}$; Micro slides, VWR Scientific Inc., West Chester, PA, USA) in batch cultures for 5 days as detailed elsewhere. ${ }^{15,16}$ Bacterial suspensions (planktonic cells) were harvested at late-exponential phase $\left(\mathrm{OD}_{600 \mathrm{~nm}}\right.$ 1.0), and the cell pellet ( $4 \mathrm{mg}$ dry weight) was kept in RNALater according to the manufacturer's protocols (Ambion, Inc., Austin, TX, USA). The biofilm (5 days-old, $\sim 84 \mathrm{mg}$ dry-weight) was removed from the glass slides using a sterile spatula, split in 3 samples ( $28 \mathrm{mg}$ dry weight each) and also kept in RNALater at $4^{\circ} \mathrm{C}$ overnight $(\sim 18 \mathrm{~h})$.

\section{Extraction of total RNA}

Initially, the RNALater solution was carefully removed using an automatic pipette without disturbing the biofilm or cell pellet. The biofilm or cell pellet was washed three times with $7.0 \mathrm{~mL}$ of cold PBS. At the third washing step, the suspension was sonicated with three pulses of $30 \mathrm{~s}$ at $7 \mathrm{~W}$ with 1 min interval on ice (Branson Ultrasonics Co., Danbury, CT, USA). After the washing-sonication procedure the biofilm (or cell) suspension was centrifuged at $5,500 \times \mathrm{g}, 4^{\circ} \mathrm{C}$, for $10 \mathrm{~min}$ and the pellets were subjected to RNA extraction according to published protocols, ${ }^{4,8}$ with some modifications. Briefly, the pellets were re-suspended in $0.75 \mathrm{ml}$ RNAse-free NAES buffer $(50 \mathrm{mM}$ sodium acetate buffer, $10 \mathrm{mM}$ EDTA and $1 \%$ SDS, w/v, pH 5.0) and vortexed for $1 \mathrm{~min}$. The same volume of acid phenol:chloroform (5:1, pH 4.5; Ambion, Inc., Austin, TX, USA) was added to the suspension, then vortexed and transferred to $2.0-\mathrm{ml}$ screw-cap microcentrifuge tubes containing $0.8 \mathrm{~g}$ of glass beads $(0.5$-mm diameter; Biospec Products, Bartlesville, OK, USA). The cells were lysed in a Mini-Bead Beater homogenizer (Biospec Products) at $4{ }^{\circ} \mathrm{C}$ for a total of $120 \mathrm{~s}$ (beat three times for $40 \mathrm{~s}$ with $1 \mathrm{~min}$ interval). The homogenized suspension was centrifuged at $10,000 \times g$ for $5 \mathrm{~min}$ at $4^{\circ} \mathrm{C}$, and the aqueous phase was collected and transferred to a microcentrifuge tube to which was added $0.75 \mathrm{ml}$ of acid phenol:chloroform (5:1, $\mathrm{pH} 4.5$ ). The tube was vortexed briefly, and centrifuged at $13,000 \times g$ for $5 \mathrm{~min}$ at $4^{\circ} \mathrm{C}$. The aqueous phase was collected and extracted with a 1:1 solution of chloroform:isoamylalcohol (24:1; Ambion, 
Inc.) once. Total RNA was precipitated using a 1/10 volume of $3 \mathrm{M}$ sodium acetate ( $\mathrm{pH}$ ) and 1 volume of isopropanol at $-20^{\circ} \mathrm{C}$ for at least $30 \mathrm{~min}$.

\section{DNAse treatments}

The RNA precipitates were recovered by centrifugation $\left(13,000 \times g, 4^{\circ} \mathrm{C}\right.$ for $\left.15 \mathrm{~min}\right)$ and the pellet washed with ice-cold $75 \%$ ethanol $(\mathrm{v} / \mathrm{v})$ three times followed by $99 \%$ ethanol; the crude RNA was resuspended in molecular grade water, and quantified spectrophotometrically (absorbance at $260 \mathrm{~nm}$, $\left.A_{260}\right)$. Extracted crude RNA was treated enzymatically with DNAse I to remove contaminant genomic DNA. Two types of commercially available DNAse I treatments were used:

1. on column DNAse I (Qiagen RNeasy Mini kit, Qiagen Sciences, MD, USA)

2. protein engineered DNAse I in solution (Turbo DNAse; Ambion Inc.).

An aliquot of the extracted RNA $(\sim 50 \mu \mathrm{g})$ was treated with the DNAse I according to the manufacturer's protocols either alone or in combinations as follows:

1. Approach T: Ambion's Turbo DNAse I protocol (2 U of Turbo DNAse I/10 $\mu$ g RNA) followed by Qiagen RNeasy MinElute (for DNAse I removal)

2. Approach Q: Qiagen's RNeasy on column DNAse I protocol (2.7 U of DNAse I/10 $\mu \mathrm{g}$ RNA)

3. $\mathrm{T}$ followed by $\mathrm{Q}$

4. Q followed by $\mathrm{T}$

\section{Determination of RNA purity and integrity}

The quality of the purified RNA was examined by:

1. $1.2 \%$ formaldehyde agarose gel electrophoresis and ethidium bromide staining $;{ }^{17}$

2. Agilent 2100 electrophoresis bioanalyzer (Agilent Technologies, Santa Clara, CA, USA); ${ }^{18}$

3. absorbance ratio $A_{260} / A_{280}$ in Tris buffer $10 \mathrm{mM}$ $\mathrm{pH}$ 7.5. ${ }^{17}$

\section{Carbohydrate analysis}

The total concentration of carbohydrates in crude RNA preparations was quantified by the phenol-sulfuric method using glucose as standard..$^{19,20}$ Since nucleic acids react in this method a correc- tion was applied based on the concentration of carbohydrate expected in RNA. ${ }^{10}$ The mathematical relationship between RNA concentration found at $260 \mathrm{~nm}$ and its carbohydrate concentration estimated by phenol-sulfuric method was determined using RNA standard (R6750, Sigma-Aldrich, St. Louis, MO, USA). Therefore, by difference it was possible to estimate the polysaccharide contamination found in the RNA.

\section{Real-time reverse transcriptase PCR (RT- PCR) analysis}

To check for genomic DNA contamination, $1 \mu \mathrm{g}$ of purified RNA (without reverse transcriptase) from each of the DNAse treatment procedures were amplified by a MyiQ real-time PCR detection system with iQ SYBR Green supermix (Bio-Rad Laboratories, Inc., CA, USA) containing specific primer sets for $g t f B .6,14$ In addition, cDNAs were synthesized from $1 \mu \mathrm{g}$ of purified RNA samples using BioRad iScript cDNA synthesis kit (Bio-Rad Laboratories, Inc., CA, USA) which contains a MMLV RNase H+ reverse transcriptase and random hexamers. The resulting cDNA was used as template in the real-time PCR step; a reaction containing only the reagents (no template control) was also included.

\section{Results}

The yield and purity of the crude preparations of RNA extracted from planktonic cells and biofilms of $S$. mutans are shown in Table 1.

Table 2 shows the yield and indicators of the RNA purified after the DNAses treatments.

In general, the combination of DNase I treatments $(\mathrm{T}+\mathrm{Q}$ and $\mathrm{Q}+\mathrm{T})$ provided better genomic DNA removal than did either treatment alone. Table 3 shows real-time RT-PCR data using purified

Table 1 - Yield and purity of the crude RNA.

\begin{tabular}{c|c|c|c}
\hline \multirow{2}{*}{$\begin{array}{c}\text { Growth } \\
\text { condition }\end{array}$} & $\begin{array}{c}\text { Yield, } \\
\mathrm{mg} / 100 \mathrm{mg}^{\mathrm{a}}\end{array}$ & $\mathrm{A}_{260} / \mathrm{A}_{280} \eta \mathrm{m}$ & \begin{tabular}{c} 
Ratio \\
\cline { 3 - 4 }$[$ Carbohydrate]/ \\
{$[\mathrm{RNA}]$}
\end{tabular} \\
\hline Planktonic cells & $9.04 \pm 0.89$ & $2.15 \pm 0.02$ & $0.17 \pm 0.03$ \\
\hline Biofilm & $0.52 \pm 0.07$ & $2.11 \pm 0.01$ & $0.30 \pm 0.04$ \\
\hline
\end{tabular}

Values are means \pm SD $(n=3) .{ }^{a}$ Dry-weight; ${ }^{b}$ RNA Sigma $=0.19$ 
Table 2 - RNA yield and estimation of genomic DNA removal after DNAse treatments.

\begin{tabular}{|c|c|c|c|c|c|c|}
\hline \multirow{2}{*}{$\begin{array}{l}\text { DNAses } \\
\text { Treatments }\end{array}$} & \multicolumn{2}{|c|}{ RNA yield mg /100 mg dry-weight } & \multicolumn{2}{|c|}{ DNA Removal (\%) } & \multicolumn{2}{|c|}{ Ratio [Carbohydrate]/[RNA]* } \\
\hline & Planktonic & Biofilm & Planktonic & Biofilm & Planktonic & Biofilm \\
\hline${ }^{\mathrm{a}} \mathrm{T}$ & $6.07 \pm 0.35$ & $0.14 \pm 0.02$ & $32.5 \pm 3.9$ & $72.5 \pm 3.0$ & $0.16 \pm 0.05$ & $0.19 \pm 0.02$ \\
\hline $\mathrm{b} T+Q$ & $3.61 \pm 0.84$ & $0.08 \pm 0.01$ & $59.9 \pm 9.4$ & $84.6 \pm 2.0$ & $0.16 \pm 0.06$ & $0.20 \pm 0.02$ \\
\hline${ }^{\circ} \mathrm{Q}$ & $4.86 \pm 0.57$ & $0.10 \pm 0.04$ & $46.0 \pm 6.4$ & $81.7 \pm 6.8$ & $0.16 \pm 0.01$ & $0.23 \pm 0.01$ \\
\hline${ }^{d} Q+T$ & $4.35 \pm 0.32$ & $0.06 \pm 0.03$ & $51.6 \pm 3.5$ & $87.6 \pm 5.9$ & $0.16 \pm 0.02$ & $0.18 \pm 0.03$ \\
\hline
\end{tabular}

Values are means $\pm \mathrm{SD}(n=3)$. ${ }^{\mathrm{T}}$ Turbo DNAse treatment + RNeasy cleanup; ${ }^{\mathrm{b}}$ Turbo DNAse treatment + RNeasy protocol; ${ }^{\mathrm{C}} \mathrm{RNeasy}$ protocol; ${ }^{\mathrm{d}} \mathrm{RN}$ easy protocol + Turbo DNAse treatment + RNeasy cleanup. "RNA Sigma $=0.19$.

Table 3 - Real-time RT-PCR data ( $C_{+}$values) using purified RNA as a template.

\begin{tabular}{c|c|c}
\hline \multirow{2}{*}{ Treatments } & \multicolumn{2}{|c}{ gtfB } \\
\cline { 2 - 3 } & Planktonic & Biofilm \\
\hline${ }^{\circ} T$ & $25.7 \pm 0.2$ & $26.2 \pm 0.3$ \\
\hline${ }^{\mathrm{b} T}+Q$ & $29.2 \pm 2.9$ & $30.2 \pm 0.3$ \\
\hline${ }^{\circ} Q$ & $24.2 \pm 0.9$ & $22.8 \pm 0.6$ \\
\hline${ }^{\mathrm{d}} \mathrm{Q}+\mathrm{T}$ & $33.0 \pm 1.0$ & $33.1 \pm 0.9$ \\
\hline
\end{tabular}

Values are means $\pm \mathrm{SD}(n=3)$. ${ }^{\top}$ Turbo DNAse treatment + RNeasy cleanup. 'Turbo DNAse treatment + RNeasy protocol. 'RNeasy protocol. dRNeasy protocol + Turbo DNAse treatment + RNeasy cleanup.

RNA (using different approaches) as a template. Clearly, RNA samples subjected to combination of DNAse I treatments provided much higher $C_{t}$ values than a single DNAse I treatment, which agrees well with the data shown in Table 2. Moreover, the approach $\mathrm{Q}+\mathrm{T}$ resulted in RNA samples with the highest $C_{t}$ values $(\geq 33)$ indicating negligible amounts of genomic DNA; the no-template control showed $\mathrm{C}_{t}$ values $\geq 34$.

Figure 1 shows the integrity of RNA extracted and purified according to different approaches.

\section{Discussion}

The procedure for RNA extraction described in this study yielded about 9.04 (or $0.52 \mathrm{mg}$ ) of crude RNA extract per $100 \mathrm{mg}$ of cell (or biofilm) dry weight (Table 1). The $A_{260} / A_{280}$ ratios were above 2.1 irrespective of whether the RNA is extracted from planktonic cells or biofilms, suggesting little or no protein contamination. In contrast, the ratio [carbohydrate] / [RNA] of crude RNA from plank- tonic cells was 0.17 whereas the same ratio for the RNA from biofilms was 0.30 , indicating presence of contaminant polysaccharides since the ratio for pure RNA (Sigma) is 0.19. Polysaccharides have been shown to interfere with cDNA synthesis, RTPCR and hybridization in northern analyses, ${ }^{10,21,22}$ and should therefore be eliminated during the RNA purification process.

For successful isolation of intact RNA, it is also important to remove as much contaminant genomic DNA as possible in an RNA preparation, ${ }^{1,23}$ which is a challenge procedure particularly for biofilms. ${ }^{9}$ Thus, each of the RNA extracts was subjected to various approaches of DNAse treatments to examine their effects on RNA yield and genomic DNA removal. The yield after DNAse I treatments was 3.61 to $6.07 \mathrm{mg}$ of RNA/100 mg of cell dry-weight and 0.06 to $0.14 \mathrm{mg}$ of RNA/100 mg of biofilm dryweight, showing an estimated 32.5 to $59.9 \%$ and 72.5 to $87.6 \%$ of genomic DNA removal (Table 2). The ratio [carbohydrate]/[RNA] for the RNA from biofilms was between 0.18 and 0.23 , indicating that most if not all of the contaminant polysaccharide was removed (Table 2). In addition, the integrity of RNA was examined by denaturating $1.2 \%$ agarose gel and lab-on-chip capillary electrophoresis ${ }^{18}$ as shown in Figure 1. For all samples of RNA, the agarose gel and the micro-fluidic capillary electrophoresis showed sharp and distinct $23 \mathrm{~S}$ and $16 \mathrm{~S}$ ribosomal RNA bands with minimal degradation. The Bioanalyzer 2100 also provides the RNA integrity number (RIN), a new tool for RNA quality assessment. ${ }^{23}$ RIN higher than 5 is considered a good total RNA quality for downstream applications, such 


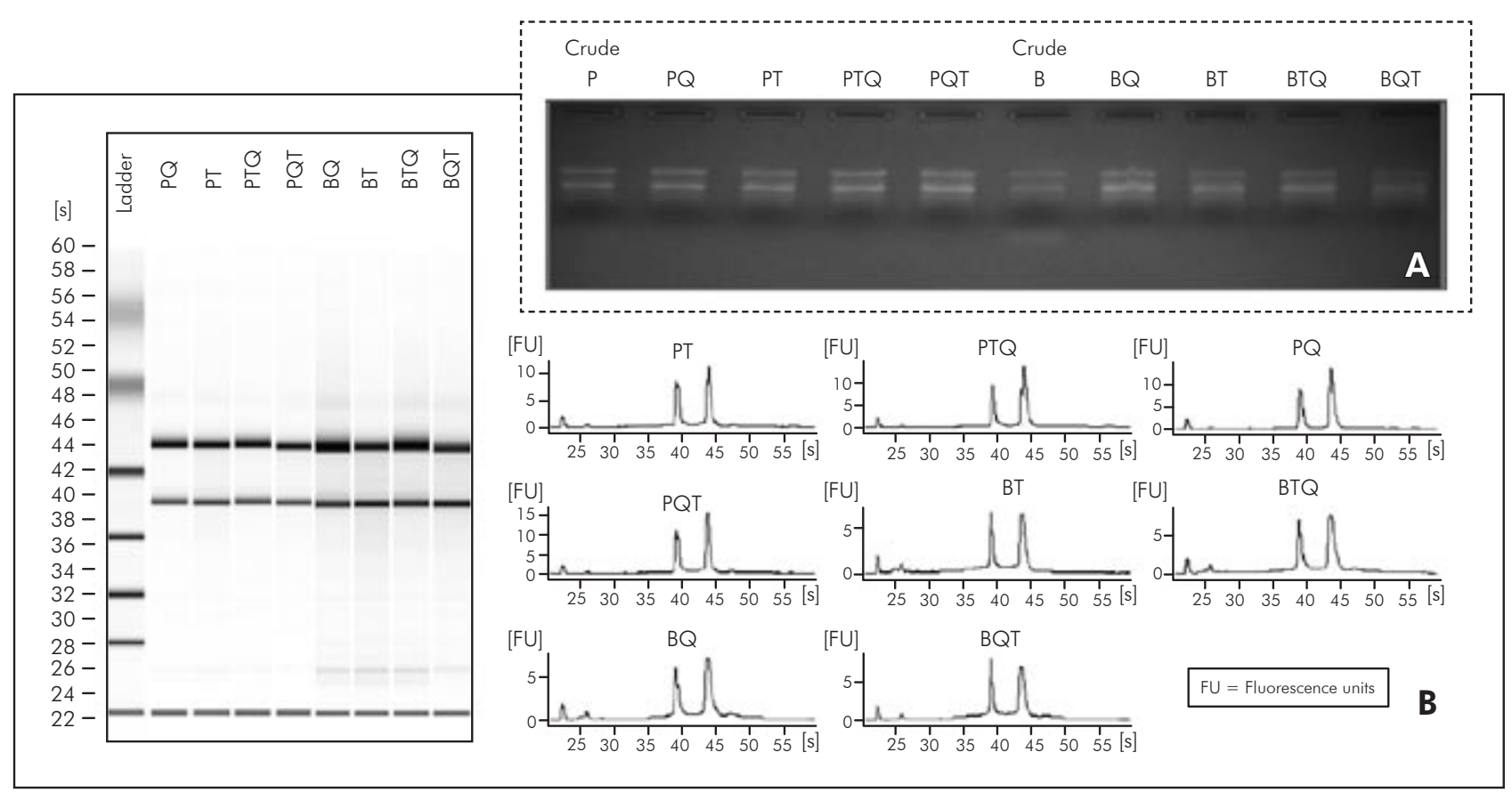

Figure 1 - Analyses of the RNA integrity of the purified samples by denaturating 1.2\% agarose gel (A) and lab-on-chip capillary electrophoresis (B). Crude P - crude RNA extracted from planktonic cells of S. mutans; PQ - RNA from S. mutans cells purified according to approach Q, PT - RNA purified according to approach T; PTQ - RNA purified according to approach TQ; PQT - RNA purified according to approach QT. Crude B - crude RNA from S. mutans biofilms; BQ - RNA from S. mutans biofilms purified according to approach Q; BT - RNA purified according to approach T; BTQ - RNA purified according to approach TQ; BQT - RNA purified according to approach QT.

a qRT-PCR. ${ }^{23}$ In the present study, the RIN in all of our purified samples was higher than 8.3.

Furthermore, the quality of RNA preparations was analyzed using real-time RT-PCR, SYBR Green I and primer-sets for $g t f B$; gtfB was selected because it is a critical virulence gene associated with extracellular polysaccharide synthesis, ${ }^{24}$ and is commonly used for $S$. mutans detection in clinical samples using qRT-PCR based experiments. ${ }^{25}$ First, the purified RNA samples $(1 \mu \mathrm{g})$ were used as templates in PCR reaction to examine for the presence of residual genomic DNA by monitoring of the increasing fluorescence intensity after each PCR cycle; a greater amount of DNA results in lower $C_{t}$ value, as a result of requiring less PCR cycles for the fluorescence emission intensity to reach the threshold. The various DNAse treatments examined in this study resulted in purified RNA samples with distinct levels of genomic DNA (Table 3). Clearly, the type, number and sequence of DNAse treatments are critical for DNA removal. The RNA treated with Qiagen's
RNeasy on column DNAse I approach (Q) was the less effective method; the Ambion's Turbo DNAse I approach $(\mathrm{T})$ was more effective than approach Q likely due to the greater catalytic efficiency of its recombinant DNAse I than the wild-type DNAse I used in Q. ${ }^{9,26}$ The combination of two DNAse I treatments was more efficient at removing the coextracted DNA from the RNA fraction than one treatment, especially for biofilms. However, Q followed by $\mathrm{T}$ (QT) was superior than T followed by Q (TQ) based on PCR data (Table 3). The RNA extracts purified using the approach QT showed detectable fluorescence signal only after 33 cycles when using the primer sets for $g t f B$ indicating only trace amounts of DNA; the $C_{t}$ values are 6.9-10.3 times higher than those obtained with RNA using approach Q or T, and 2.9-3.8 times higher than the values from RNA purified with the TQ approach. Since the quantity of DNA (or cDNA) doubles every cycle during the exponential phase, a difference of only 3 cycles would represent as much as 8 times more (or less) 
DNA template. Thus, it is evident that QT is more effective in removing genomic DNA than other approaches. It is still unclear how exactly the sequence of the DNAse I treatments affects the genomic DNA removal. We are currently investigating the putative mechanisms involved in DNA removal by the combination of DNAse treatments.

Lastly, cDNA pools were synthesized from $1 \mu \mathrm{g}$ of purified RNA using random hexamers. The amplification (with gtfB primers) of either two- or fivefold serial dilution of cDNAs from RNA purified according to protocol QT provided correlation coefficient of 0.98-0.99 and slope between -3.289 and -3.365 (98.2 to $101.4 \%$ amplification efficiency), which is within the range of acceptable slope $(-3.0$ to -3.5 ) indicating little or no PCR inhibitors. The

\section{References}

1. Bustin SA, Benes V, Nolan T, Pfaffl MW. Quantitative real-time RT-PCR - a perspective. J Mol Endocrinol. 2005 Jun;34(3):597-601.

2. Morrison TB, Weis JJ, Wittwer CT. Quantification of lowcopy transcripts by continuous SYBR Green I monitoring during amplification. Biotechniques. 1998 Jun;24(6):954-62.

3. Abranches J, Lemos JA, Burne RA. Osmotic stress responses of Streptococcus mutans UA159. FEMS Microbiol Lett. 2006 Feb;255(2):240-6.

4. Chen YY, Weaver CA, Mendelsohn DR, Burne RA. Transcriptional regulation of the Streptococcus salivarius 57.I urease operon. J Bacteriol. 1998 Nov;180(21):5769-75.

5. Chia JS, Lee YY, Huang PT, Chen JY. Identification of stress-responsive genes in Streptococcus mutans by differential display reverse transcription-PCR. Infect Immun. 2001 Apr;69(4):2493-501.

6. Fujiwara T, Hoshino T, Ooshima T, Hamada S. Differential and quantitative analyses of mRNA expression of glucosyltransferases from Streptococcus mutans MT8148. J Dent Res. 2002 Feb;81(2):109-13.

7. Gagnon G, Vadeboncoeur C, Frenette M. Phosphotransferase system of Streptococcus salivarius: characterization of the ptsH gene and its product. Gene. 1993 Dec;136(1-2):27-34.

8. Kuhnert WL, Quivey RG Jr. Genetic and biochemical characterization of the F-ATPase operon from Streptococcus sanguis 10904. J Bacteriol. 2003 Mar;185(5):1525-33.

9. Keinänen-Toivola MM, Revetta RP, Santo Domingo JW. Identification of active bacterial communities in a model drinking water biofilm system using $16 \mathrm{~S}$ rRNA-based clone libraries. FEMS Microbiol Lett. 2006 Apr;257(2):182-8. no-template control showed negligible amplification ( $\geq 34$ cycles).

\section{Conclusions}

In conclusion, a method (QT approach) that yields high-quality RNA from both planktonic cells and especially biofilms of $S$. mutans in sufficient quantity for real-time RT-PCR analyses was described in this study.

\section{Acknowledgements}

The authors are grateful to Dr. Simone Duarte for technical assistance. This research was supported in part by the Brazilian Funding Agency "Coordenação de Aperfeiçoamento de Pessoal de Nível Superior (CAPES)", research grant BEX 0494/05-4.

10. Manning K. Isolation of nucleic acids from plants by differential solvent precipitation. Anal Biochem. 1991 May;195(1):45-50.

11. Rijpens NP, Jannes G, van Asbroeck M, Rossau R, Herman LM. Direct detection of Brucella spp. in raw milk by PCR and reverse hybridization with 16S-23S rRNA spacer probes. Appl Environ Microbiol. 1996 May;62(5):1683-8.

12. Sharma AD, Gill PK, Singh P. RNA isolation from plant tissues rich in polysaccharides. Anal Biochem. 2003 Mar;314(2):31921.

13. Ajdic D, McShan WM, McLaughlin RE, Savic G, Chang J, Carson MB et al. Genome sequence of Streptococcus mutans UA159, a cariogenic dental pathogen. Proc Natl Acad Sci USA. 2002 Oct;99(22):14434-9.

14. Koo H, Seils J, Abranches J, Burne RA, Bowen WH, Quivey $\mathrm{RG} \mathrm{Jr}$. Influence of apigenin on $\mathrm{gtf}$ gene expression in Streptococcus mutans UA159. Antimicrob Agents Chemother. 2006 Feb;50(2):542-6.

15. Chatfield CH, Koo H, Quivey RG Jr. The putative autolysin regulator LytR in Streptococcus mutans plays a role in cell division and is growth-rate regulated. Microbiology. 2005 Feb;151(Pt 2):625-31.

16. Koo H, Hayacibara MF, Schobel BD, Cury JA, Rosalen PL, Park YK et al. Inhibition of Streptococcus mutans biofilm accumulation and polysaccharide production by apigenin and tt-farnesol. J Antimicrob Chemother. 2003 Nov;52(5):7829.

17. Sambrook J, Fritsch EF, Maniatis T. Molecular cloning: a laboratory manual. $2^{\text {nd }}$ ed. New York: Cold Spring Harbor Laboratory Press; 1989. 
- Isolation and purification of total RNA from Streptococcus mutans in suspension cultures and biofilms

18. Mueller O, Lightfoot S, Schroeder A. RNA integrity number (RIN) - standardization of RNA quality control. Agilent Application Note 2004; Publication 5989-1165EN:1-8.

19. Dubois M, Gilles KA, Hamilton JK, Rebers PA, Smith F. Colorimetric method for determination of sugars and related substances. Anal Chem. 1956;28(2):350-6.

20. Kopec LK, Vacca-Smith AM, Bowen WH. Structural aspects of glucans formed in solution and on the surface of hydroxyapatite. Glycobiology. 1997 Oct;7(7):929-34.

21. Shioda M, Murakami-Murofushi K. Selective inhibition of DNA polymerase alpha by a polysaccharide purified from slime of Physarum polycephalum. Biochem Biophys Res Commun. 1987 Jul;146(1):61-6.

22. Wanqian L, Bochu W, Chuanren D, Biao L. A method for isolating functional RNA from callus of Dendrobium candidum contented rich polysaccharides. Colloids Surf B Biointerfaces. 2005 May;42(3-4):259-62.

23. Fleige S, Pfaffl MW. RNA integrity and the effect on the real-time qRT-PCR performance. Mol Aspects Med. 2006 Apr-Jun;27(2-3):126-39.

24. Aoki H, Shiroza T, Hayakawa M, Sato S, Kuramitsu HK. Cloning of a Streptococcus mutans glucosyltransferase gene coding for insoluble glucan synthesis. Infect Immun. 1986 Sep;53(3):587-94.

25. Hoshino T, Kawaguchi M, Shimizu N, Hoshino N, Ooshima T, Fujiwara T. PCR detection and identification of oral streptococci in saliva samples using gtf genes. Diagn Microbiol Infect Dis. 2004 Mar;48(3):195-9.

26. Moore S. Pancreatic DNAse. In: Boyer PD (Ed.). The Enzymes. New York: Academic Press; 1981. chapter 15 